\title{
IMPROVING THE AFFINITY OF COTTON FABRIC TOWARDS DIRECT DYE USING ECO-FRIENDLY ULTRASOUND ENERGY
}

\author{
Khaled EL-Nagar ${ }^{(I)}$, Mahmoud El-Gazery ${ }^{(2)}$ and Ferial Tera ${ }^{(I)}$ \\ (1) Textile Metrology Lab, National Institute for Standards, Tersa street, EL-Haram, , P.O. Box: 136 Giza, \\ Code No. 12211, Giza Egypt \\ (2) Ultrasonic Metrology Lab, National Institute for Standards, Tersa street, EL-Haram, , P.O. Box: 136 \\ Giza, Code No. 12211, Giza Egypt
}

Corresponding Author: Prof. Dr. Khaled E. El-Nagar Email khnagare@hotmail.com

\section{ABSTRACT}

irect dyes are the most common dyes for cotton fabric but the disadvantage of this

$\mathrm{D}$ kind of dyestuff are their low washing wet fastnesses, consumed alkali, time and energy. In this study, cotton fabrics were treated with ultrasound of powers of 0-250 Watt for different periods ranging from 0 to 60 mins. Using Globar salt solution with different concentrations ranged from $0-30 \mathrm{~g} / 1$ as a treatment media. The resulted samples after exposure for 30 mins to ultrasound energy and dyed at room temperature $\left(25^{\circ} \mathrm{C}\right)$ without salt showed comparable results as for the conventionally dyed samples that treated with $30 \mathrm{~g} / \mathrm{l}$ global salt for $30 \mathrm{~min}$ at $90^{\circ} \mathrm{C}$. Moreover the resulted samples showed some improvements with respect to the fastness to washing, rubbing and light as well as the colour compoents expressed as 'L' brightness, 'a' red-green, and 'b' yellow-blue components.

Key words : Ultrasonic, Cotton fabric, direct dye, colour components, fastness properties

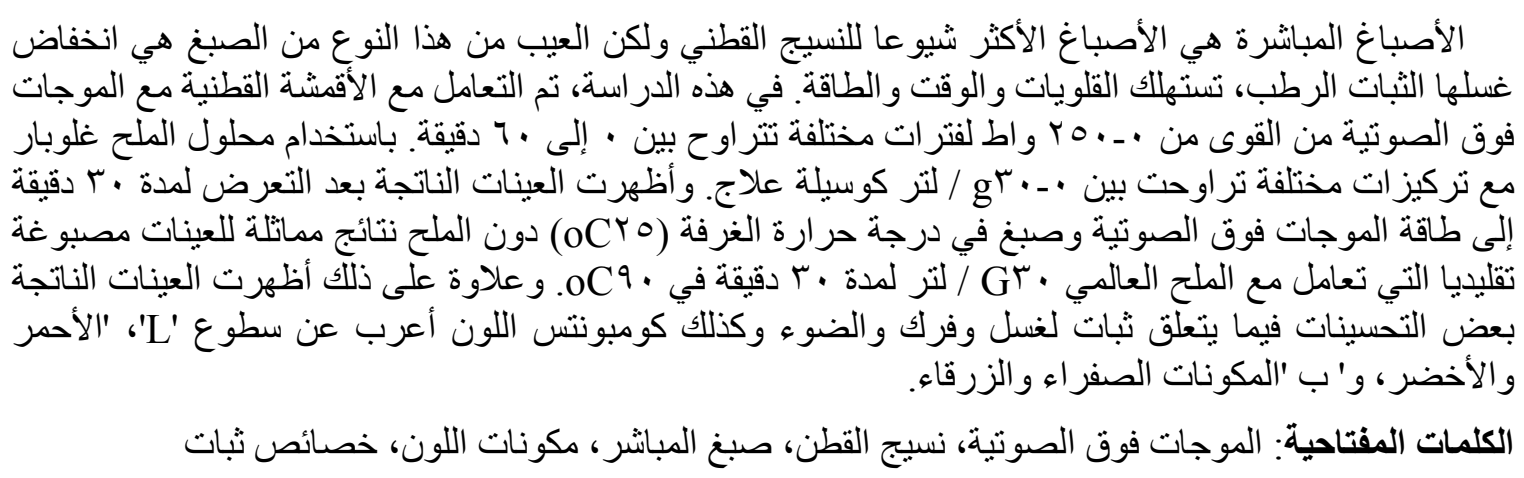

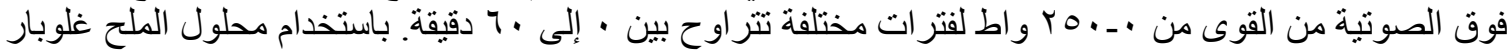

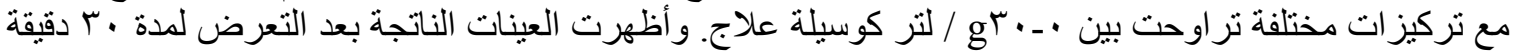

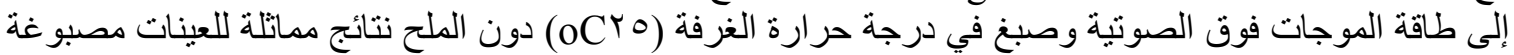

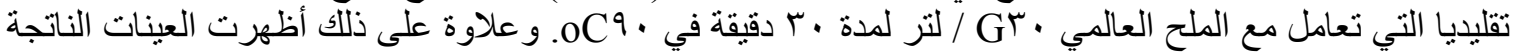

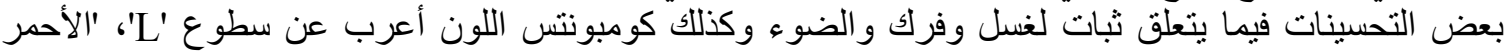

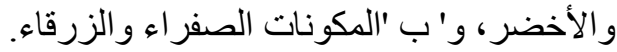
الكلمات المفتاحية: الموجات فوق الصوتية، نسيج القطن، صبغ المباشر ، مكونات اللون، خصائص ثبات

\section{INTRODUCTION}

Several surface modification methods are employed to modify the polymer surfaces such as chemical treatments, thermal treatments, mechanical treatment, and electrical treatment were reported (El-Nagar et al 2006). The chemical and biological effects of ultrasound were first reported by Loomis as early as 1927 (Suslick1989). Ultrasound spans the frequencies of roughly $18-40 \mathrm{kHze}$ beyond human hearing. In practice, three ranges of frequencies are reported for three distinct uses of ultrasound: low frequency or conventional power ultrasound $(20 \mathrm{kHz}-100 \mathrm{kHz})$, medium frequency ultrasound $(300 \mathrm{kHz}$ $-1000 \mathrm{kHz}$ ) and diagnostic or high frequency ultrasound (2 MHz -10 MHz) (Peters 1996; Ince ET AL 2001; Vajnhandl 2005 ). 
Ultrasound produces chemical effects through several different physical mechanisms and the most important nonlinear acoustic process for sonochemistry is cavitation. This is the formation of gas-filled microbubbles or cavities in a liquid, their growth and, under proper conditions, implosive collapse. The dynamics of cavities growth and collapse depend on the local environmental surrounding. Ultrasound waves consist of expansion (rarefaction) and compression cycles. Compression cycles exert a positive pressure on the liquid and push molecules together, while expansion cycles exert a negative pressure and pull molecules apart. Cavities can be generated during the expansion of a sound wave cycle with sufficient intensity, that the distance between the molecules exceeds the critical molecular distance (Elmaaty et al, 2014, Kamel M. et al., 2005; Mason T, 1999; Vajnhandl 2005 and Suslick et al. 1986).

The influence of ultrasound on the dyeing medium has three effects namely, breaking up of the micelles and high molecular weight aggregates into smaller and uniform dispersion in the dye bath. Degassing of fiber for more capillary action and facilitate the dye-fiber contact and accelerating the rate of diffusion of the dye inside the fiber by breaking the boundary layers covering the fiber and accelerating the interaction between dye and fiber. These mechanisms affect individually or in combinations (Contamine F. et al., 1994; Teli M. et al., 2000; Mason T., 1999 \&1991; Mason T. and Lorimer L., 1990).

Ultrasonic irradiation has been shown to be effective for the treatment of chemical contaminants in aqueous solutions (Kotronarou et al 1992; Hua et al 1995; Hua and Hoffmann 1996 and 1997; Kang and Hoffmann 1998; Weavers 1998). The chemical effects of ultrasonic irradiation over the frequency range of $20 \mathrm{kHz}-1000 \mathrm{kHz}$ are the direct result of the formation of cavitations bubbles. Rarefaction and compression cycles induced by the ultrasonic pulses in the liquid generate cavities that grow until they reach a critical size and then due to resonant absorption of energy the bubbles undergo a violent collapse. The fast implosion of the cavitations bubbles produces a quasi-adiabatic heating of the vapor phase inside the cavity that yields localized high temperatures (thousands of K) and pressures. Water molecules under such extreme conditions undergo thermal dissociation to yield $\mathrm{H}$ and $\mathrm{OH}$ radicals. Organic solutes in the vicinity of a collapsing bubble or partitioned into the gas phase of the bubble undergo thermal decomposition and/or react with the reactive radicals. The purpose of that study is to demonstrate the technical feasibility of the degradation of Alkylphenol Ethoxylate Surfactants (APE) in water under ultrasound irradiation. The chemical processes generated in the sonochemical reactor are able to operate on the different chemical features (.Desrallats et al 2000).

Some examples of ultrasonic energy are military and non-military exploration of sea floor and sonar systems, non-destructive testing in material engineering, medical therapy and diagnosis. Ultrasonic energy is also widely used for cleaning and degreasing of parts and assemblies in automotive and other industries (Mason T.J, 1991). The potential use of ultrasound in leather, chemical and textiles industries is to reduce processing time, pollution load and to get improvement in the product quality (Sivakumar et al. 2003 and Kamel et al., 2003). Akalin (2004) studied the effects of ultrasonic energy on the wash fastness of reactive dyes, after dyeing with the conventional dyeing method used the ultrasonic textile washing and he mentioned that,it could be a competitive alternative to conventional textile washing techniques. 
The aim of this article is to reduce both consumed energy and dyeing period of cotton fabric with Sirius reactive dye. Ultrasonic assistant dyeing technique with different powers and treatment periods was used to achieve this goal.

\section{EXPERIMENTAL WORKS}

\section{MATERIALS}

Fabric: Fabric is a Mill-Scoured and bleached 100\% cotton fabric was used in this work, with a plain weave $1 / 1$ structure, and of weight $120 \mathrm{~g} / \mathrm{m}^{2}$, produced by Kafr El-Dawar Co., Egypt. The fabrics were further treated with a solution containing $0.5 \mathrm{~g} / 1$ soap and $0.5 \mathrm{~g} / 1$ $\mathrm{Na}_{2} \mathrm{CO}_{3}$ at a temperature of $70^{\circ} \mathrm{C}$ for $1 \mathrm{hr}$, thoroughly washed and air dried at room temperature.

Dye: Dye used in this research is a direct dye of commercial name SiriusTM that was kindly supplied by Dyestar Co. Egypt.

Chemicals: Globar salt, dihydrogen phosphate, disodium phosphate, sodium chloride, L-Histiden mono-hydrochloride are of commercial grade chemical that are used in the dyeing and assessing of the washing and perspiration fastnesses.

\section{ULTRASONIC DYEING SYSTEM}

Dyeing experiments were carried out in especially stainless cell. The cell was designed to allow to conditioning water to flow maintaining the cell temperature at $25 \pm 3^{\circ} \mathrm{C}$. The detailed design of the cell and the setup arrangements are shown in Fig. (1). The samples were processed using Branson sonifier 450 attached to solid titanium horn of 0.5 -inch diameter, It was excited at $20 \mathrm{KHz}$ with variable energy up to $250 \mathrm{Watt}$. (Nour et al 2010).

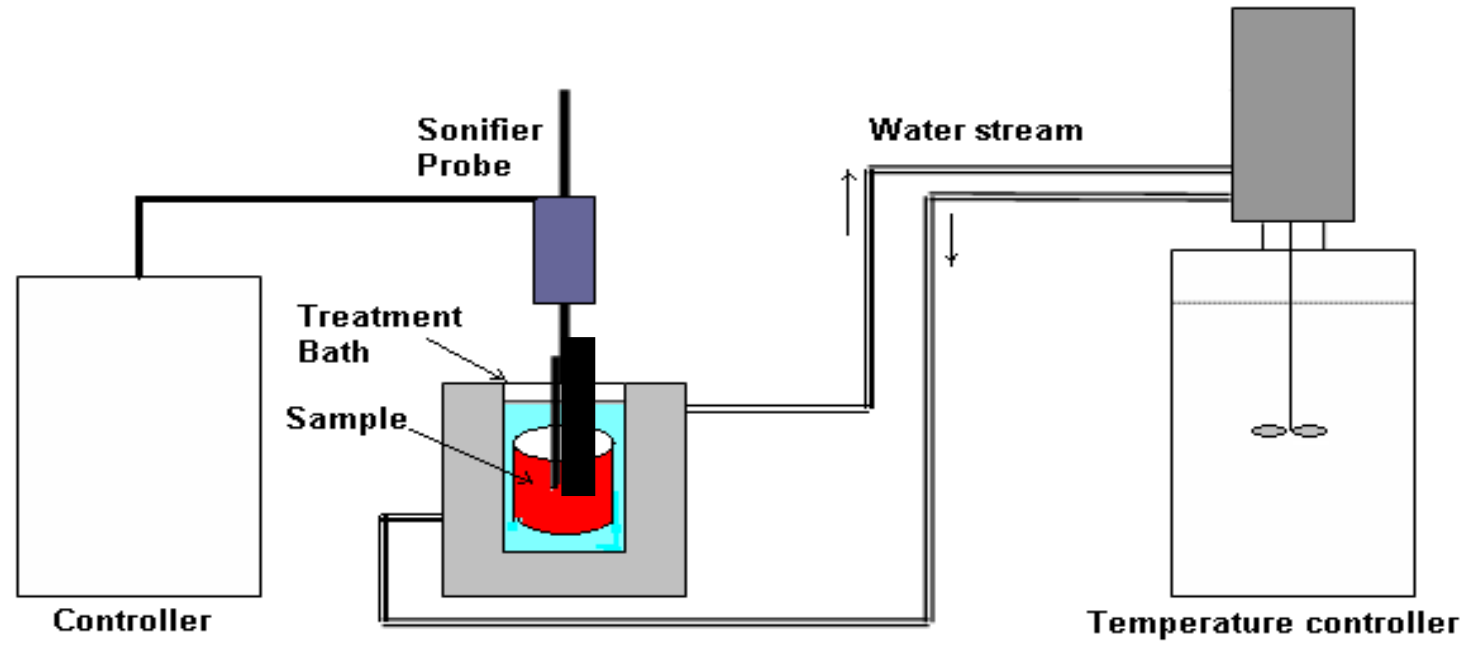

Figure 1: Schematic diagram of the ultrasonic treatment system 
Different concentrations with the same liquor ration 1:20 of Globar salt were used through dyeing to study the effect of presence of salt on dyeability when using ultrasonic energy

\section{CONVENTIONAL DYEING PROCEDURE}

Conventionally dyed samples that treated with $30 \mathrm{~g} / \mathrm{l}$ global salt for $30 \mathrm{~min}$ at $90^{\circ} \mathrm{C}$ for 45 minutes, the liquor ratio was 1:20 .dye concentration was $2 \%$ (owf)

\section{TESTING AND ANALYSIS}

\section{COLOR MEASUREMENTS}

The examined samples were tested for the whiteness and yellowness indices to investigate the surface degradation by using Macbeth double beam spectrophotometer (SDL-UK) attached with integrating sphere. All measurements were measured in comparison with the standard white tile that has traceability to SI measurement system. The used spectrophotometer was calibrated for photometric and wavelength scales. The samples were preconditioned before testing at standard environmental conditions of temperature $\left(20 \pm 2{ }^{\circ} \mathrm{C}\right)$ and relative humidity $(65 \pm 5 \%)$ using standard conditioning room at Textile Metrology Lab (TML), in the National Institute for Standards (NIS, Egypt). The same instrument was also used to measure the color parameters, e.g., 'L' lightness, 'a' redgreen, and 'b' yellow-blue color components in accordance with the CIE-Lab color measuring system ( ASTM, 2001, El-Nagar, 2005).

\section{MECHANICAL PROPERTIES}

The treated and untreated samples were tested for their tensile and elongation behaviors using Zweigle of model Z010, at a tension speed of $100 \mathrm{~mm} / \mathrm{min}$ under the standard atmospheric conditions (temperature $=20 \pm 2^{\circ} \mathrm{C}$ and relative humidity $=65 \pm 5 \%$ ). The testing was carried out according to ASTM D412-98a.The measurements were carried out three times, and the results indicated in this paper are the mean values attached with their uncertainty values [EURACHEM/CITAC Guide CG4].

\section{FASTNESS PROPERTIES}

The treated samples were tested for washing and rubbing color fastness properties according to AATCC as per the conditions specified in the AATCC methods No. 68, 8, 15 and 16A (1989).

\section{RESULTS AND DISCUSSIONS}

Ultrasound energy results in the decomposed of some surface fibres into reactive fragment species. At the same time, The power also producing small defects on the fiber surfaces (Yudasaka et al 2000; Shelimov et al 1998; . Lu et al 1996). The reactive species/radicals produced by decomposition reacted easily with dyes or finishing chemicals (Koshio et al 2001). 


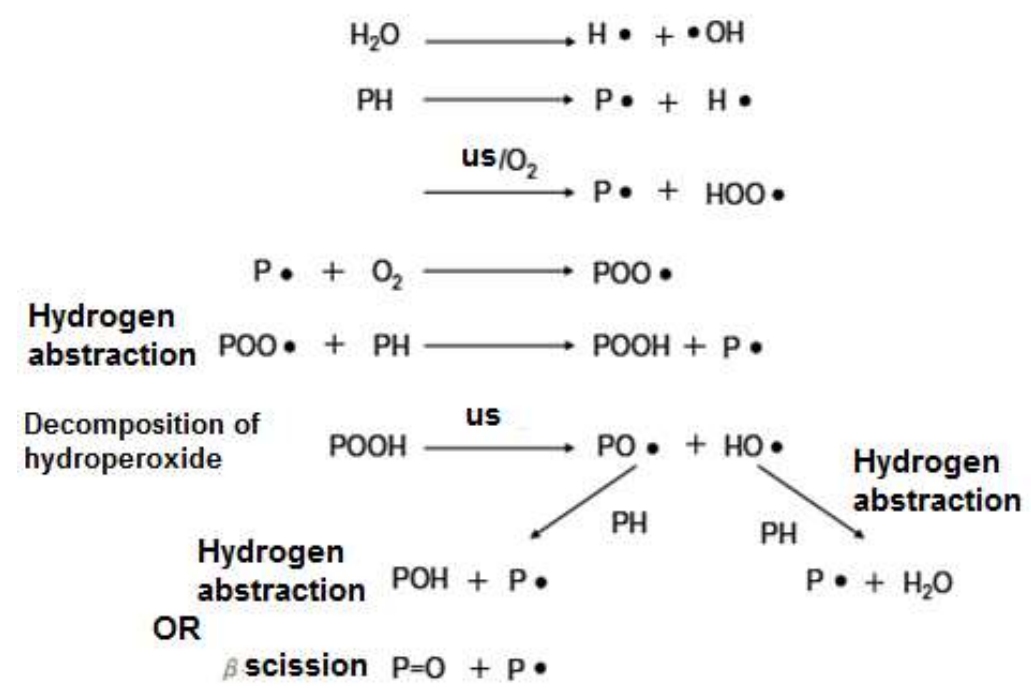

Figure (2): Possible effects of ultrasonic energy on polymeric structure (PH) (Rabek, 1995 and Woo et al., 2007).

The possible interaction of US in presence of oxygen and water on the polymeric materials is to produce many free radicals $\left(\mathrm{P}^{\circ}, \mathrm{POO}^{\circ}, \mathrm{HOO}^{\circ}, \mathrm{H}^{\circ}, \mathrm{HO}^{\circ}\right)$ that are explained in Figure 2. The presence of these free radicals on the cotton substrate was the responsible active sites for the attachment of the treatment solutions (dye, salts, and intermediates) to the cotton substrate.

The formation of free radicals during sonolysis can be explained from the following equations of Figure 3 (Suslick 1990; Neppolian et al 2004; Beckett and Hua 2000). The rapid implosion of cavitation bubbles is accompanied by adiabatic heating of the vapor phase of the bubble that produces a localized and transient high temperature and pressure. The temperatures and pressures associated with bubble collapse have been estimated to be on the order of $5000^{\circ} \mathrm{C}$ and $500 \mathrm{~atm}$, respectively (Suslick 1990). Water vapor under these conditions undergoes a thermal dissociation to yield extremely reactive radicals, $\mathrm{H}^{\bullet}$ and $\mathrm{OH}^{*}$, and in the presence of oxygen these yield $\mathrm{HO}_{2} \cdot$ As a result, organic compounds present near the bubble/water interface can undergo thermal decomposition, and/or other secondary reactions (Kang and Hoffmann 1998). Reactions also occur in the bulk aqueous phase by the oxidative effect of hydrogen peroxide, which has been observed to form in sonolytic systems

$$
\begin{aligned}
& \mathrm{H}_{2} \mathrm{O}+\mathbf{U S} \rightarrow \mathrm{OH}^{*}+\mathrm{H}^{*} \\
& 2 \mathrm{OH}^{\cdot} \rightarrow \mathrm{H}_{2} \mathrm{O}_{2} \\
& 2 \mathrm{O} \rightarrow \mathrm{O}_{2} \\
& \text { In the presence of oxygen } \\
& \left.\left.\left.\left.\mathrm{O}_{2}+\right)\right)\right)\right) \rightarrow 2 \mathrm{O} \\
& \mathrm{O}_{2}+\mathrm{O}^{\circ} \rightarrow \mathrm{O}_{3} \\
& \mathrm{O}_{2}+\mathrm{H}^{\cdot} \rightarrow{ }^{\cdot} \mathrm{OOH}\left(\text { or } \mathrm{OH}^{\cdot}+\mathrm{O}\right) \\
& \mathrm{O}^{*}+\mathrm{OOH}^{*} \rightarrow \mathrm{OH}^{*}+\mathrm{O}_{2} \\
& \mathrm{O}+\mathrm{H}_{2} \mathrm{O} \rightarrow 2 \mathrm{OH}^{\cdot}
\end{aligned}
$$


Figure (3): Possible effects of ultrasonic energy on water (Suslick 1990; Neppolian et al 2004; Beckett and Hua 2000).

The very high temperature due to cavitations effects of ultrasound energy can lead to decreasing the crystallinity of cellulosic fibers' surface and substitution of hydroxyl groups $\mathrm{OH}$ by organic acids and formation of anhydride at 1,4;2,3 and 1,6 positions of the anhydroglucose unit of cellulose. Further surface depolymerization sets is due to breakage of 1,6 glucosidic linkages of cellulose backbone followed by pyrolysis of smaller products. There is also a tendency of crosslinking reactions during thermal degradation of the cellulose polymer (Abdel-Kareem and El-Nagar 2005).

\section{EFFECT OF US ON FABRIC WEIGHT:}

Figure 4 shows the effect of both the ultrasonic power and its duration on the fabric weight. It is noticed that by increasing the power the fabric weight loss increased up to 30 min duration, longer time show insignificant decrement especially for $200 \mathrm{~W}$ and $250 \mathrm{~W}$. Loss in the fabric weight ranged from 1.3 ( at $50 \mathrm{~W}$ ) to $10 \%$ (at $250 \mathrm{~W}$ ). This indicates that the ultrasonic exposure has surface effect with acceptable fabric deterioration on the fabric samples. These phenomena can be explained by the previously mentioned effects reported by Suslick 1990; Neppolian et al 2004; Beckett and Hua 2000.

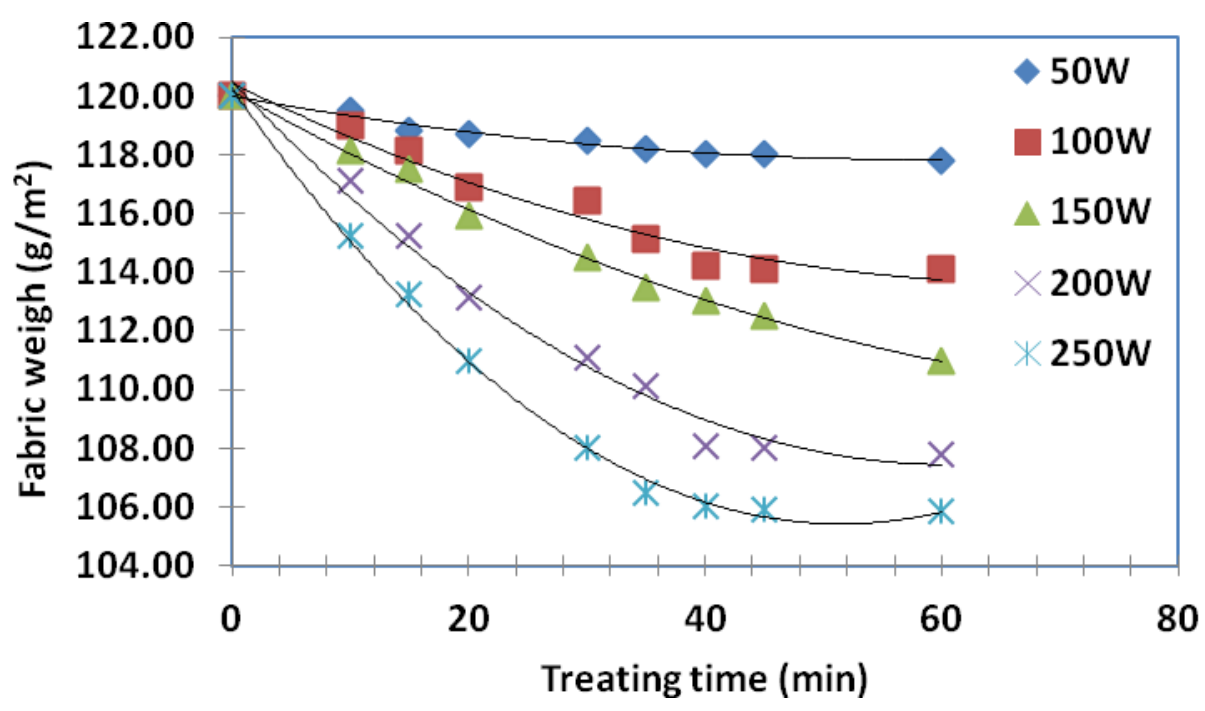

Figure (4): Effect of ultrasonic treatment time and power on cotton fabric weight.

\section{EFFECT OF US ON TENSILE STRENGTH (KG.F), ELONGATION (\%) AND CREASE RECOVERY ANGEL $\left(^{\circ}\right)$ :}

The effect of ultrasonic power ranged from $50 \mathrm{~W}$ to $250 \mathrm{~W} / \mathrm{cm}^{2}$ on mechanical behavior expressed as tensile strength for different exposure time ranged from 0 to 80 minutes was showed in Figure 5. Loss in tensile strength was found with lower percentage ranged from $1.3 \%$ (at $50 \mathrm{~W} / \mathrm{cm}^{2}$ ) to $7.4 \%$ (at $200 \mathrm{~W} / \mathrm{cm}^{2}$ ) and significantly increased to $15.6 \%$ at $\left(250 \mathrm{~W} / \mathrm{cm}^{2}\right)$. Slight decreasing of tensile strength with time for each individual ultrasonic power ranged from $50 \mathrm{~W} / \mathrm{cm}^{2}$ to at $200 \mathrm{~W} / \mathrm{cm}^{2}$ was observed while a significant decrement for 250 at $\mathrm{W} / \mathrm{cm}^{2}$. 


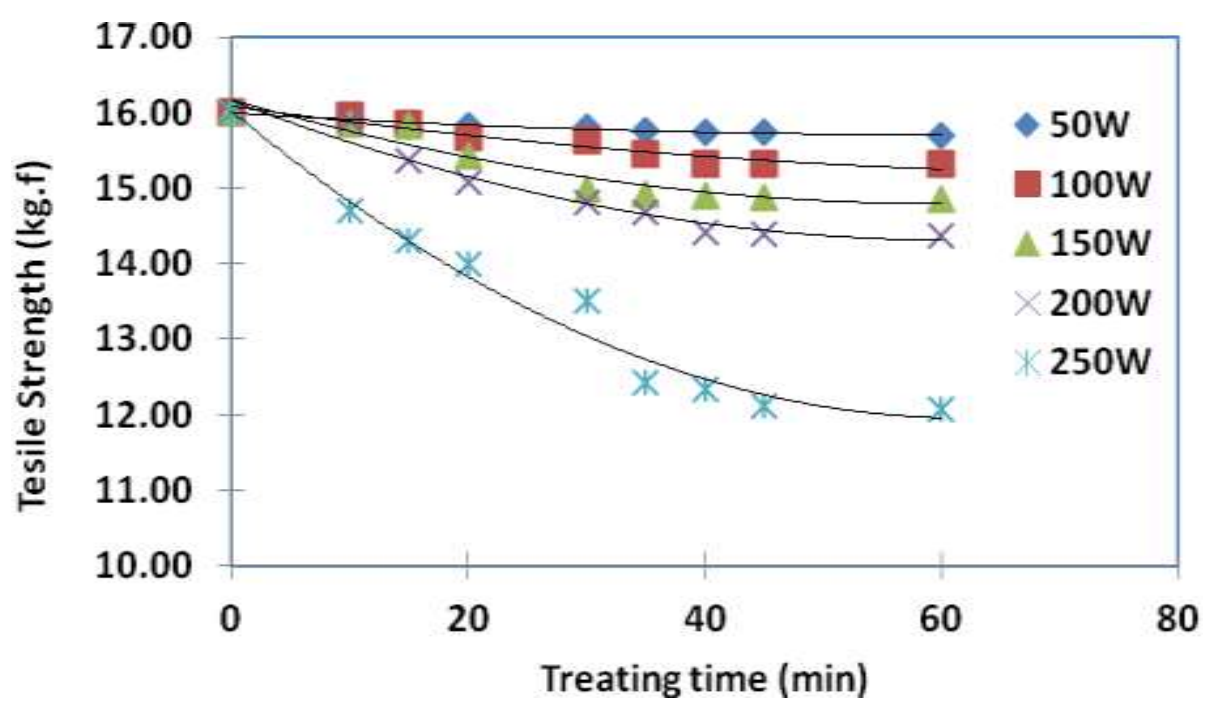

Figure (5): Effect of ultrasonic treatment time and power on cotton fabric tensile strength..

Elongation \% for the examined samples was studied in relation to ultrasonic power and exposure time. Figure 6 shows that the direct proportional relation between the exposure time and elongation percent for each ultrasonic power studied. It is also indicated that the elongation percent is exponential increment with exposure time for ultrasonic power up to $200 \mathrm{~W} / \mathrm{cm}^{2}$ while increased linearly for $50 \mathrm{~W} / \mathrm{cm}^{2}$.

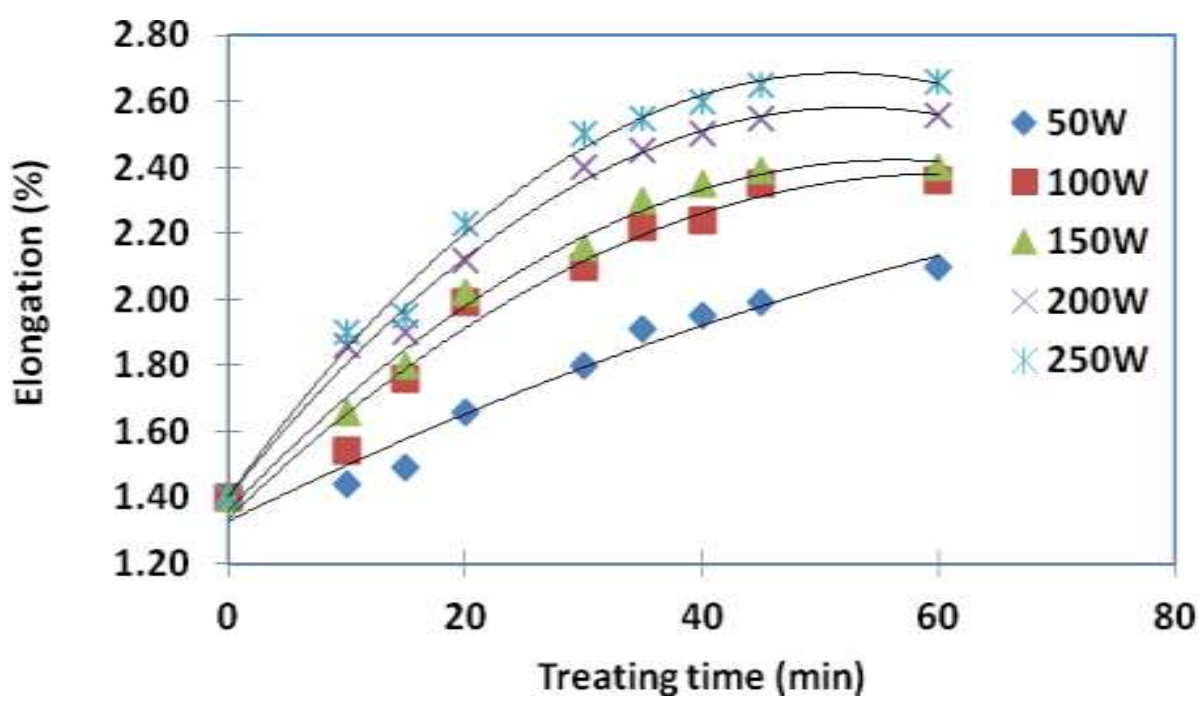

Figure (6): Effect of ultrasonic treatment time and power on cotton fabric elongation (\%).

Figure 7 shows the effect of ultrasonic exposure time ranged from 0 to 60 minutes on crease recovery angel for each studied ultrasonic power ranged from $50 \mathrm{~W} / \mathrm{cm}^{2}$ to 250 $\mathrm{W} / \mathrm{cm}^{2}$. The effect is linear for $50 \mathrm{~W} / \mathrm{cm}^{2}$. Crease recover angel was improved by $6.6 \%$ while by $60 \%$ for $250 \mathrm{~W} / \mathrm{cm}^{2}$. It is clear also that, the increasing of the crease recovery 
angel with increasing exposure time for ultrasonic powe ranged from $100 \mathrm{~W} / \mathrm{cm}^{2}$ to 250 $\mathrm{W} / \mathrm{cm}^{2}$ is exponential realation.

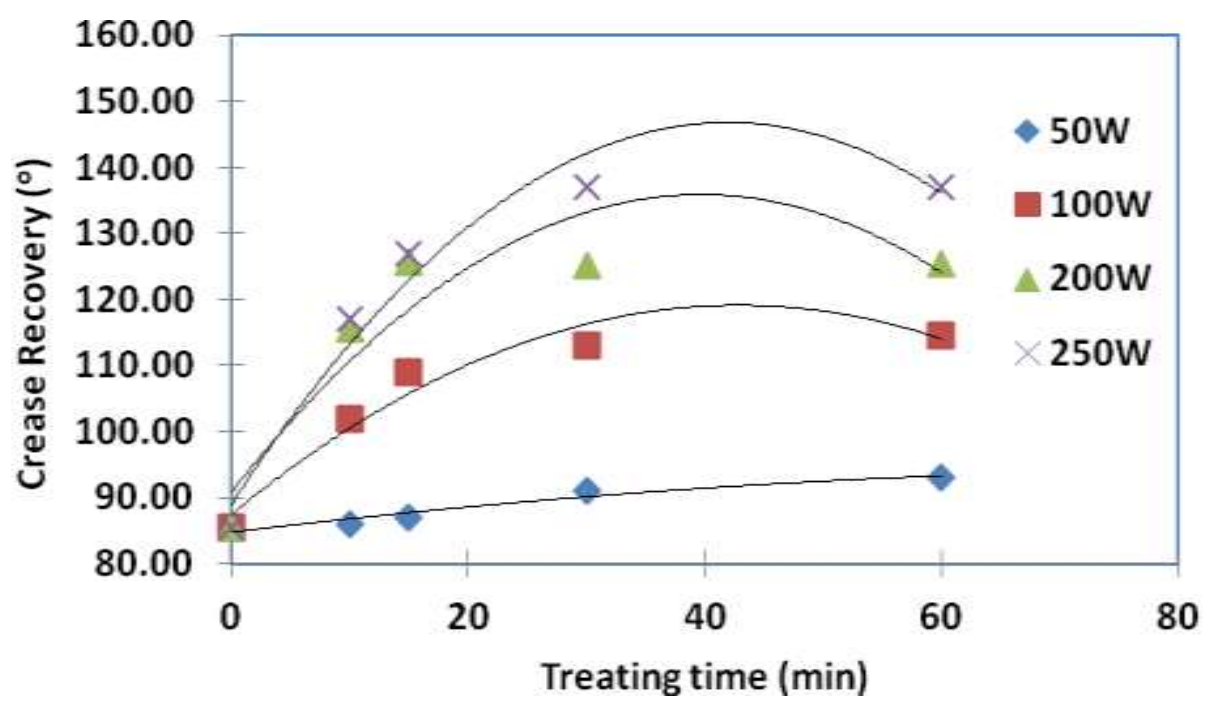

Figure (7): Effect of ultrasonic treatment time and power on cotton crease recovery angel.

By comparing the obtained results from the effect of ultrasonic treatment time and power on fabric weight, tensile strength, elongation \% and crease recovery angel the treatment conditions at $250 \mathrm{~W}$ for 30 minutes at room temperature and $30 \mathrm{~g} / \mathrm{l} \mathrm{Globar}$ salt as treatment media were chosen for this work

\section{EFFECT OF GLOBAR SALT CONCENTRATION ON CIE COLOUR ARAMETERS (L,A AND B):}

Table 1 shows the effect of Globar salt concentration on the colour components expressed as 'L' brightness, 'a' red-green, and 'b' yellow-blue parameters at ultrasonic power of $250 \mathrm{~W} / \mathrm{cm}^{2}$ and exposure time for 30 minutes. The results were compared for the conventional dyeing conditions (liquor ratio, dyeing time, temperature and salt concentration as indicated in table 1), conventional assisted by ultrasonic power and ultrasonic dyeing technique at room temperature without salt. Brightness values ' $L$ ' decreased with increasing the salt concentration for all studied rang (0 to $30 \mathrm{~g} / \mathrm{l})$. Red green 'a' component increased with increasing the salt concentration. Yellow -blue 'b' component slightly decreased with increasing the salt concentration. Colour change expressed as " $\Delta \mathrm{E}$ " increased with increasing the salt concentration in relation to undyed fabric. By comparing the samples dyed with $30 \mathrm{~g} / \mathrm{l}$ that used for conventional technique with and without ultrasonic power and that carried out using ultrasonic power of 250 $\mathrm{W} / \mathrm{cm}^{2}$ without salt and at room temperature (without boiling) we can say that using ultrasonic power as a clean and ecofriendly energy can give comparable results with low energy consumption and low chemical pollution resulted from using salt in the dyeing process. 
Table (1): Effect of Globar salt concentration on CIE color change.

\begin{tabular}{|l|l|l|l|l|}
\hline Salt Conc. (g/l) & ' $\mathbf{L}^{\prime}$ & $\mathbf{~} \mathbf{}^{\prime}$ & $\mathbf{~} \mathbf{b}^{\prime}$ & $\Delta \mathbf{E}^{\mathbf{a}}$ \\
\hline $\begin{array}{l}\text { Blank } \\
\text { (Undyed fabric) }\end{array}$ & 96.14 & -0.51 & 0.93 & 0.00 \\
\hline $\mathbf{0}$ & 97.12 & 38.94 & 68.49 & 78.24 \\
\hline $\mathbf{1 0}$ & 81.00 & 43.21 & 65.15 & 79.15 \\
\hline $\mathbf{1 5}$ & 63.00 & 58.00 & 65.96 & 93.54 \\
\hline $\mathbf{2 0}$ & 60.11 & 59.60 & 64.00 & 94.28 \\
\hline $\mathbf{3 0}$ & 52.00 & 69.00 & 61.00 & 101.92 \\
\hline Conventional $^{(\mathbf{b})}$ & 52.15 & 72.10 & 59.00 & 102.86 \\
\hline Conventional + US $^{(\mathbf{c})}$ & 25.62 & 81.33 & 53.00 & 119.93 \\
\hline US $^{(\mathbf{d})}$ & 54.30 & 65.90 & 61.00 & 98.84 \\
\hline
\end{tabular}

( a) Colour change by comparing to undyed blank cotton fabric $(\mathrm{L}=96.14, \mathrm{a}=-0.51$ and $\mathrm{b}=0.93$ )

(b) Conventional, using 2\% dye (owf), liquor ratio 1:20, 30g.1 Globar salt, at $90^{\circ} \mathrm{C}$ for 45 minutes.

(c) Conventional assisted dyeing the fabric treated by US ( $250 \mathrm{~W}$ for $30 \mathrm{~min}$ )

(d) Ultrasonic conditions using ultrasonic before dyeing followed by dyeing at liquor ratio $1: 20$, at $30^{\circ} \mathrm{C}$ for 45 mins.

\section{EFFECT OF USING US ON COLOUR FASTNESS TO WASHING, RUBBING AND LIGHT.}

Fastness properties of the dyed sample are very important quality criteria for dyeing technique and table 2 indicates the colour fastness to washing, rubbing and light for the three studied techniques namely ultrasonic, conventional and conventional assisted ultrasonic. Conventional assisted ultrasonic techniques showed a slight increment for washing (4/5 alteration and staining) while has the same results for rubbing (4 for wet and $4 / 5$ for dry) and light fastness ( 6 on the blue scale).

Table (2) Effect of using US on colour fastness to washing, rubbing and light.

\begin{tabular}{|c|c|c|c|c|c|}
\hline \multirow{2}{*}{ Dyeing technique } & \multicolumn{2}{|c|}{ Washing Fastness ${ }^{(a)}$} & \multicolumn{2}{|c|}{ Rubbing Fastness (a) } & \multirow{2}{*}{ Light Fastness $^{(b)}$} \\
\hline & $\begin{array}{l}\text { Color } \\
\text { change }\end{array}$ & Staining & Wet & Dry & \\
\hline US & 4 & $4 / 5$ & 4 & $4 / 5$ & 6 \\
\hline Conventional & 4 & 4 & 4 & $4 / 5$ & 6 \\
\hline Conventional+ US & $4 / 5$ & $4 / 5$ & 4 & $4 / 5$ & 6 \\
\hline
\end{tabular}

(a) Rating on grey scale (5 means no change or staining and 1 for high change and staining). 
(b) Rating on standard blue scale (1 for low fastness and 8 for highly stable to light)

\section{CONCLUSION}

This research aimed to study the using ultrasonic power for dyeing cotton fabric samples with direct dye as a clean and ecofriendly energy. It was used in this research to eliminate or reduce using Globar salt at room temperature. Effect of ultrasonic exposure time ranged from 0-60 minutes for different ultrasonic powers ranged from $50 \mathrm{~W} / \mathrm{cm}^{2}$ to $250 \mathrm{~W} / \mathrm{cm}^{2}$ on mechanical behavior expressed as tensile strength, elongation percent and recovery angel and colour components expressed as ' $\mathrm{L}$ ' brightness, 'a' red-green and 'b' yellow -blue in addition to overall colour change in comparison with the undyed samples. Using ultrasonic power decreases the tensile strength up to $10 \%$ for 60 minutes exposure time, increased both the elongation and crease recovery angel. 'a' value was the significant colour component expressing the dyeability of the studied samples due to the original colour of direct dye used.

\section{ACKNOWLEDGMENT}

The authors thank Dr. Abbas Gomaa for his helpful discussions and support.

\section{REFERENCES}

1. Abdelkareem O. A, El-Nagar $K h(2005)$, Non-Destructive Methods to investigate the Deterioration Extent of Coptic Egyptian Textiles, JTATM, 4(4), 1-15.

2. Akalin M., Merdan N., Kocak D. and Usta I(2004).," Effects of ultrasonic energy on the wash fastness of reactive dyes", Ultrasonics 42 161-164.

3. ASTM D 1682 (1989).

4. ASTM E275-01, ASTM E925-02 and ASTM E308-9(2001), Volume 6-01.

5. Beckett M.A., Hua I. (2000), Environ. Sci. Technol. 343944

6. Contamine F., Faid F., Ilhelm A., Berlan J., Delmas H(1994). Chemical reactions under ultrasound, Chem. Eng. Sci, 49(24B): 5865.

7. Desrallats H., Hung H., and Hofmfmann M., Degradation of Alkylphenol Ethoxylate Surfactants in Water with Ultrasonic Irradiation Environ. Sci. Technol. 2000, 34, 311-317

8. Elmaaty T. A.,, Elnagar K., Hassan S., Gamal H(2014) ., Antibacterial activity and dyeing characteristics of some azo-pyazole disperse dyes using eco-friendly ultrasound energy for PET fabric., International Journal of Scientific \& Engineering Research, Volume 5, Issue 5, 1156-61

9. El-Nagar Kh., Suzan H. Sand, Amal S. Mahmoud and Ramadan A. (2005), "Mechanical properties and stability to light exposure for dyed Egyptian cotton fabrics with Natural and synthetic dyes", journal of natural fibers, 2 (3), pp. 49-59

10. El-Nagar K., Saudy M. A. ,Eata A. I., Masoud M. M. (2006), DC pseudo plasma discharge treatment of polyester textile surface for disperse dyeing, JOTI, Vol. 97 No. 2 111-117

11. EURACHEM/CITAC Guide CG4(2000), Quantifying Uncertainty in Analytical measurement, Second Edition, QUAM,

12. Hua, I.; Hochemer, R.; Hoffmann, M. R(1995). J. Phys. Chem., 992335. 
13. Hua, I.; Hoffmann, M. R1996). Environ. Sci. Technol., 30, (864.

14. Hua, I.; Hoffmann, M. R(1997). Environ. Sci. Technol., 31, 2237.

15. Ince N.H., Tezcanli G., Belen R. K., Apikyan I. G(2001). Ultrasound as a catalyzer of aqueous reaction systems: the state of the art and environmental applications. Applied Catalysis B: Environmental. 29 167-76.

16. Kamel M. M., El-Shishtawy, Hanna H. L., Ahmed N. S. (2003), Polymer international, 52(3), 373.

17. Kamel M. M., El-Shishtawy, Yussef B. M. and Mashaly H(2005), Ultrasonic assisted dyeing,III Dyeing of wool with lac as a natural dye", Dyes and pigments 65 103-110.

18. Kang, J.-W; Hoffmann, M. R(1998). Environ. Sci. Technol., 323194.

19. Koshio A., M. Yudasaka, M. Zhang, and S. Iijima(2001), NANO LETTERS, Vol. 1, No. $7361-363$

20. Kotronarou, A.; Mills, G.; Hoffmann, M. R(1992). Environ. Sci. Technol., 262420.

21. Lu, L. K.; Lago, R. M.; Chen, Y. K.; Green, M. L. H.; Harris, P. J. F.; Tsang, S. C(1996). Carbon, 34814.

22. Mason T, Lorimer J(1990)., A general introduction to sonochemistry. In Mason T., Editor, Sonochemistry: the use of ultrasound in chemistry. The Royal Society of Chemistry, 1-26.

23. Mason T. (1991), "Practical sonochemistry; user's guide to applications in chemistry and chemical engineering". Chichester: Ellis Horwood Limited;:27-34.

24. Mason T. (1999)., "Sonochemistry", New York: Oxford Univ. Press;

25. Neppolian B., Park J.S., Choi H. (2004), Effect of Fenton-like oxidation on enhanced oxidative degradation of para-chlorobenzoic acid by ultrasonic irradiation, Ultrasonics Sonochemistry $11273-279$

26. Nour M., Eid A.,El-Nagare K and Abdel Aziz F(2010), Preparation and Characterisation of Polyethylene/Clay Nanocomposites as a Flame Retardant Materials Using Ultrasonic

Technique, Polymers \& Polymer Composites, Vol. 18, No. 3, 159-166

27. Peters D1996. Ultrasound in materials chemistry. Journal of Materials Chemistry;6(10):1605e18.

28. Rabek, J.F. 1995. Polymer Photodegradation; Mechanisms and Experimental Methods. Chapman and Hall. London. pp. 185-207 (Chapter 3).

29. Sivakumar V. and Gangadhar P. (2003)," Studies on the use of power ultrasound in leather dyeing", Ultrasonics sonochemistry , 1085-94.

30. Shelimov, K. B.; Esenaliev, R. O.; Rinzler, A. G.; Huffman, C. B.; Smalley, R. E(1998). Chem. Phys. Lett., 282429.

31. Suslick K. S., Cline R. E. and Hammerton D. A., J. Am. Chem. Soc., 1986; 108:5641

32. Suslick K. S1989. Ultrasound; its chemical, physical, and biological effects. New York: VCH Publishers;.

33. Suslick K.S(1990)., Science 2471439. 
34. Teli M. (2000), Paul R. and Pardeshi P., Colourage, 43(12),

35. Vajnhandl S., Le Marechal A. M. (2005), Ultrasound in textile dyeing and the decolouration/ mineralization of textile dyes, Dyes and Pigments 65 89-101.

36. Weavers, L. K.; Ling F. H.; Hoffmann, M. R1998. Environ. Sci. Technol., 32, 2, 2727.

37. Woo, R.S.C., Chen, Y., Zhu, H., Li, J., Kim, J.-K. and Leung, C.K.Y(2007). Environmental degradation of epoxy-organoclay nanocomposites due to UV exposure. Part I: Photo-degradation. Composites Science and Technology. 67(15-16): 3448-56.

38. Yudasaka, M.; Zhang, M.; Jabs, C.; Iijima, S(2000). Appl. Phys. A,71, 449. 